\title{
233.
}

\section{ADDITION AU MÉMOIRE SUR LA FORME CANONIQUE DES FONCTIONS BINAIRES.}

[From the Journal für die reine und angewandte Mathematik, (Crelle), tom. LIV. (1857), p. 292.]

Dans le mémoire "Sur la forme canonique des fonctions binaires" (p. 48 de ce volume [232]) j'ai dit que M. Sylvester avait en outre étendu sa théorie aux fonctions binaires des degrés pairs 4 et 6 ; j’aurais dû dire, des degrés pairs 4,6 et 8 . J'ai aussi omis de faire observer que les termes canonisant et lambdaüque appartenaient à M. Sylvester. Enfin en citant dans la note les mémoires de M. Sylvester qui ont rapport à cette théorie j'ai omis de citer le mémoire "On the Calculus of Forms otherwise the Theory of Invariants, § VIII. (Camb. and Dublin Math. Journal, t. Ix. [1854], p. 93) section qui porte le titre "On the Reduction of a Sextic Function of Two Variables to the Canonical Form."

Londres, 16 Juillet, 1857. 